\title{
PERHITUNGAN NILAI KETIDAKPASTIAN PADA PENGUJIAN SEDIMEN SUNGAI DENGAN TEKNIK FLUORESENSI SINAR-X (XRF)
}

\author{
Uncertain Value Calculation of Stream Sediment Testing Using X-Ray \\ Fluorescence Technique
}

\author{
YAYAH ROHAYATI \\ Puslitbang Teknologi Mineral dan Batubara \\ Jalan Jend. Sudirman 623 Bandung 40211 \\ Telp. (022) 6030483, Fax. (022) 6003373 \\ e-mail: yayah.rohayati@esdm.go.id
}

\begin{abstract}
ABSTRAK
Laboratorium Pengujian Pusat Penelitian dan Pengembangan Teknologi Mineral dan Batubara telah menyiapkan prosedur rutin untuk analisis mineral industri dengan teknik fluoresensi sinar-X (XRF). Data yang dilaporkan harus memenuhi persyaratan Komite Akreditasi Nasional (KAN), sesuai dengan SNI 19-17025:2000 butir 5.10 tentang pelaporan analisis. Tulisan ini menguraikan perhitungan ketidakpastian hasil pengukuran dengan teknik XRF dalam pengujian mineral sedimen sungai. Sumber-sumber ketidakpastian dapat terjadi selama proses penyediaan percontoh seperti saat penimbangan, peleburan percontoh dengan zat pelebur, pencacahan intensitas unsur-unsur yang diamati, pembuatan kurva kalibrasi dan lain-lain. Dari hasil perhitungan nilai ketidakpastian pada pengujian sedimen sungai dengan teknik fluoresensi sinar-X (XRF), diperoleh nilai ketidakpastian gabungan sebagai berikut: kadar $\mathrm{SiO}_{2} 2,05 \%, \mathrm{Al}_{2} \mathrm{O}_{3}$ 0,62\%, $\mathrm{Fe}_{2} \mathrm{O}_{3}$ 0,58\%, $\mathrm{TiO}_{2}$ 0,03\%1, $\mathrm{MgO}$ 0,091\%, $\mathrm{CaO}$ 0,12\%, $\mathrm{Na}_{2} \mathrm{O} 0,099 \%, \mathrm{~K}_{2} \mathrm{O}$ 0,13\%, $\mathrm{P}_{2} \mathrm{O}_{5}$ 0,012\%, $\mathrm{MnO}$ 0,029\%, $\mathrm{As}_{2} \mathrm{O}_{3}$ 0,002\%, $\mathrm{BaO} 0,018 \%, \mathrm{CeO}_{2}$ 0,004\%, $\mathrm{Cr}_{2} \mathrm{O}_{3}$ 0,002\%, $\mathrm{CuO} 0,008 \%$, $\mathrm{NiO} 0,003 \%, \mathrm{PbO} 0,004 \%, \mathrm{Rb}_{2} \mathrm{O}$ 0,006\%, $\mathrm{SO}_{3}$ 0,040\%, $\mathrm{SrO} 0,002 \%, \mathrm{~V}_{2} \mathrm{O}_{5} \quad 0,002 \%, \mathrm{Y}_{2} \mathrm{O}_{3} \quad 0,002 \%, \mathrm{ZnO} 0,002 \%$ dan $\mathrm{ZrO}_{2}$ 0,008\%. Pada pelaporan hasil uji analisis rutin mengunakan aplikasi pengujian sedimen sungai, nilai hasil perhitungan ketidakpastian pengukuran ini dapat dilaporkan memenuhi syarat SNI/IEC 17025:2017. Nilai ketidakpastian ini dapat digunakan untuk pengujian percontoh mineral oksida lainnya yang mempunyai data konsentrasi oksida hampir sama dan preparasi pembuatan cuplikan sama dengan cuplikan sedimen sungai, seperti untuk percontoh uji mineral, tanah, felspar, granit dan zeolit.
\end{abstract}

Kata kunci: ketidakpastian, sedimen sungai, fluoresensi sinar-X, analisis, laboratorium pengujian

\begin{abstract}
Testing Laboratory of Research and Development Center for Mineral and Coal Technology has developed a routine procedure for analyzing industrial minerals by X-ray fluorescence (XRF) techniques. The reported analytical figures should fulfill the requirement of Indonesian National Accreditation Body (KAN) according to SNI 19-17025:2000 point 5.10 reporting results. This paper describes the quantifying uncertainty in the analytical measurement using XRF technique for stream sediment mineral analysis. The uncertainty sources may occur during sample preparation, such as weighing, sample fusing, counting element intensities, making a calibration curve and others.
\end{abstract}


Results of uncertainty measurements by the XRF technique are: $\mathrm{SiO}_{2} 2.05 \%, \mathrm{Al}_{2} \mathrm{O}_{3} 0.62 \%, \mathrm{Fe}_{2} \mathrm{O}_{3} 0.58 \%, \mathrm{TiO}_{2}$ $0.031 \%, \mathrm{MgO} 0.091 \%, \mathrm{CaO} 0.12 \%, \mathrm{Na}_{2} \mathrm{O} 0.099 \%, \mathrm{~K}_{2} \mathrm{O} 0.13 \%, \mathrm{P}_{2} \mathrm{O}_{5} 0.012 \%, \mathrm{MnO} 0.029 \%, \mathrm{As}_{2} \mathrm{O}_{3} 0.002 \%, \mathrm{BaO}$ $0.018 \%, \mathrm{CeO}_{2} 0.004 \%, \mathrm{Cr}_{2} \mathrm{O}_{3} 0.002 \%, \mathrm{CuO} 0.008 \%, \mathrm{NiO} 0.003 \%, \mathrm{NiO} 0.003 \%, \mathrm{PbO} 0.004 \%, \mathrm{Rb}_{2} \mathrm{O} 0.006 \%$, $\mathrm{SO}_{3} 0.040 \%, \mathrm{SrO} 0.002 \%, \mathrm{~V}_{2} \mathrm{O}_{5} 0.002 \%, \mathrm{Y}_{2} \mathrm{O}_{3} 0.002 \%, \mathrm{ZnO} 0.002 \%$ and $\mathrm{ZrO}_{2} 0.008 \%$. Analysis results using stream sediment application shows that the value of the uncertainty measurement fulfilled the requirement of SNI / IEC 17025: 2017. This uncertainty value can be used for testing other oxide mineral samples that have oxide concentration data and preparation for making samples nearly the same as stream sediment samples, such as for soil, feldspar, granite and zeolite mineral samples.

Keywords: uncertainty, stream sediment, X-ray fluorescence, analysis, testing laboratory

\section{PENDAHULUAN}

Dalam SNI/IEC 17025:2017 disebutkan bahwa laboratorium pengujian dan kalibrasi setiap mengeluarkan data hasil analisis dan kalibrasi harus mencantumkan nilai ketidakpastian, tidak terkecuali pengujian dengan teknik XRF. Hasil perhitungan nilai ketidakpastian pada pengujian sedimen sungai dapat disertakan pada setiap pelaporan hasil uji. Tentu saja aplikasi pengujian yang digunakan sama atau sejenis dengan material uji (kurva kalibrasi untuk setiap material uji berbeda pada aplikasi alat XRF). Pengujian menggunakan teknik XRF, terlebih dahulu perlu dibuat suatu aplikasi atau program pengujian sesuai dengan material yang akan diuji, seperti sedimen sungai, pasir kuarsa, zirkon, pasir besi, bijih mangan, logam tanah jarang/LTJ, fosfat, bijih nikel, batugamping, kapur, bauksit dan oksida-oksida lainnya serta logam. Setiap aplikasi akan berbeda pada unsur-unsur yang akan ditetapkan begitu juga kurva kalibrasinya. Apabila kurva kalibrasi untuk setiap jenis material sudah tersedia dalam aplikasi software, jika ada contoh rutin yang mau melakukan pengujian, analis/teknisi tinggal melakukan validasi ke CRM/standar menggunakan cuplikan CRM/standar dan dibandingkan dengan data dari sertifikat. Apabila hasil sudah memenuhi standar yang ditentukan, aplikasi tersebut dapat digunakan untuk analisis percontoh.

Pada umumnya, tujuan pengukuran adalah untuk menentukan nilai besaran ukur, sedangkan yang dimaksud dengan proses pengukuran adalah suatu proses yang meliputi penentuan spesifikasi besaran ukur, metode pengukuran dan prosedur pengukuran. Secara umum, hasil pengukuran hanya merupakan taksiran atau pendekatan nilai besaran ukur. Oleh karena itu hasil tersebut hanya lengkap bila disertai dengan pernyataan ketidakpastian taksiran tersebut. Ketidakpastian adalah suatu parameter yang menetapkan rentang nilai yang didalamnya diperkirakan nilai benar yang diukur berada dan untuk menghitung rentang nilai tersebut dikenal sebagai pengukuran ketidakpastian (Kantasubrata, 2014; KAN, 2002). Ketidakpastian adalah ukuran sebaran yang secara layak dapat dikaitkan dengan nilai terukur yang memberikan rentang, terpusat pada nilai terukur, yang di dalam rentang tersebut terletak nilai benar dengan kemungkinan tertentu. Ketidakpastian hasil pengukuran mencerminkan kurangnya pengetahuan yang pasti tentang nilai besaran ukur. Hasil pengukuran setelah dikoreksi terhadap kesalahan sistematik masih berupa taksiran nilai besaran ukur karena masih terdapat ketidakpastian yang berasal dari pengaruh acak dan koreksi kesalahan sistematik yang tidak sempurna. Konsep ketidakpastian didasarkan kepada besaran teramati yang diperoleh dengan pengukuran. Hal ini berbeda dengan konsep ideal kesalahan yang didasarkan pada besaran yang tidak dapat diketahui. Kesalahan pengukuran terdiri dari 2 komponen, yaitu komponen acak dan sistematik. Kesalahan acak disebabkan oleh besaran berpengaruh yang tidak dapat diramalkan, stokastik terhadap waktu dan bervariasi terhadap ruang. Kesalahan sistematik disebabkan oleh besaran berpengaruh yang dapat diamati terhadap hasil pengukuran. (KAN, 2002). Nilai ketidakpastian diperoleh dari memadukan semua kesalahan yang terjadi selama melakukan pengujian. Sumber-sumber ketidakpastian dalam pengujian terjadi pada saat pemercontohan, preparasi percontoh, kalibrasi peralatan, instrumen, kesalahan random, kesalahan sistematik, dan personil. 
Sumber informasi yang diperlukan untuk pengukuran ketidakpastian diperoleh dari spesisifikasi pabrik atau sertifikat kalibrasi alat, data pustaka atau data dari handbook, logbook laboratorium atau validasi metode (Kantasubrata, 2014). Misal dalam perhitungan statistik untuk uji profisiensi laboratorium pengujian, suatu laboratorium yang sebelumnya mempunyai data hasil analisis yang tidak masuk dalam range (outlier), setelah memberikan nilai ketidakpastian laboratorium tersebut datanya menjadi masuk ke dalam range. Dalam era pasar global metode untuk mengevaluasi dan menyatakan ketidakpastian harus dapat diterima di dunia sehingga data pengukuran yang dilakukan dapat dibandingkan dengan mudah. Ketidakpastian yang dihitung pada tulisan ini disesuaikan dengan Pedoman Evaluasi dan Pelaporan Ketidakpastian Pengukuran, KAN DP.01.23 (KAN, 2002).

Data hasil perhitungan ketidakpastian pengukuran yang diperoleh dapat digunakan dalam analisis rutin untuk percontoh mineral: batuan, tanah, felspar, granit dan oksida-oksida lainnya yang berada pada range CRM yang digunakan pada pembuatan kurva kalibrasi dan juga percontoh yang dapat larut pada flux 5:1 ( $\left.\mathrm{LiBO}_{2}\right)$.

\section{METODE}

Dalam melakukan analisis percontoh sedimen sungai dengan teknik XRF spektrometri, dilakukan tahapan-tahapan pengujian:

a. Penimbangan percontoh;

b. Penyediaan cuplikan percontoh. Tahapan penyediaan cuplikan percontoh ini terdiri dari peleburan, pengamatan cacahan countrate unsur yang dianalisis dan perubahan signal elektrik pada data pembacaan berupa intensitas;

c. Pembuatan kurva kalibrasi. Intensitas senyawa/unsur dalam percontoh uji disubstitusikan pada kurva kalibrasi untuk mendapatkan konsentrasi senyawa/unsur bersangkutan.

Beberapa penyebab ketidakpastian dalam tahapan pelaksanaan pengerjaan di atas adalah:

a. Penimbangan. Ketidakpastian baku penimbangan terdiri dari linearitas timbangan, pengulangan (repeatability), ketidakpastian baku gabungan dan ketidakpastian bentangan/diperluas;

b. Penyediaan cuplikan percontoh. Terdiri dari ketidakpastian pada preparasi/penyiapan percontoh, ketidakpastian pembacaan data cacahan count-rate atau biasa dalam teknik spektrometri disebut counting statistic dan ketidakpastian peralatan yang disebabkan belum/tidak stabilnya peralatan akibat fluktuasi tegangan listrik;

c. Ketidakpastian pada pembuatan kurva kalibrasi. Ketidakpastian ini disebabkan adanya perbedaan harga antara data aktual dan data dari pembacaan kurva kalibrasi yang diwakili dengan persamaan linear yakni $y=$ $\mathrm{a}+\mathrm{bx}$.

Nilai ketidakpastian yang diakibatkan oleh penimbangan dapat dianggap sama untuk semua senyawa yang terdapat dalam percontoh yang dianalisis. Ketidakpastian counting statistic dipengaruhi oleh waktu radiasi sinar-X terhadap percontoh dalam detik, sedangkan ketidakpastian peralatan sangat dipengaruhi alat yang digunakan seperti jenis kristal pengurai, detektor yang dipakai, tekanan vakum dan kestabilan peralatan elektronik (Sumadi dan Rohayati, 2003).

Seperangkat spektrometer fluoresensi sinar-X seri sequential wavelength dispersive (WDXRF) tipe ZSX Primus IV merk Rigaku dan alat pendukung seperti timbangan analitik 4 desimal, mesin peleburan, tungku listrik (furnace), oven, cawan $\mathrm{Pt} / \mathrm{Au}$, cetakan $\mathrm{Pt} / \mathrm{Au}$, cawan porselin, dll. Certified Reference materials (CRM) sedimen sungai (GSD-1 sampai dengan GSD-7, produksi IGGE - Institute of Geophysical and Geochemical Prospecting, People's Republic of China), MA-N (granit, produksi GIT-IWG Groupe International de Travail preperred designation of GIT and IWG), GXR-1 jasperoid dan GXR-5 tanah (produksi USGS-AEG-United States Geological Survey, Reston) dan NCS DC 73312a dan NCS DC 73313a yang diproduksi oleh China National Analysis Center For Iron dan Steel dan flux $\mathrm{LiBO}_{2}$ merk Claisse produksi Quebec Canada merupakan bahan-bahan yang digunakan dalam studi ini. 
Dalam metode pengujian kuantitatif dengan XRF, sebelumnya harus dibuat terlebih dahulu suatu aplikasi/program pengujian sesuai dengan bahan atau material yang akan diuji, penginputan unsur-unsur yang akan diuji, kadar konsentrasi CRM yang digunakan, puncak unsur yang berimpitan, metode preparasi yang digunakan, jenis dan jumlah volume flux, perhitungan konsentrasi CRM, pembuatan kurva kalibrasi, koreksi faktor dII. CRM yang dipergunakan pada pembuatan kurva kalibrasi adalah GSD-1 sampai dengan GSD-7, MA-N, GXR-1 dan GXR-5.

Pada perhitungan ketidakpastian ini, aplikasi atau program yang digunakan adalah sedimen sungai, yaitu untuk mengakomodasi pengujian mineral sedimen sungai, lempung, batuan dengan kandungan kadar antara: $\mathrm{SiO}_{2}=41,50-71,28 \%$, $\mathrm{Al}_{2} \mathrm{O}_{3}=6,63-38,17 \%, \mathrm{Fe}_{2} \mathrm{O}_{3}=0,47-35,74 \%$, $\mathrm{MnO}=0,03-0,15 \%, \mathrm{MgO}=0,04-4,14 \%, \mathrm{CaO}=$ $0,22-7,52 \%, \mathrm{Na}_{2} \mathrm{O}=0,14-5,84 \%, \mathrm{~K}_{2} \mathrm{O}=0,06-$ $5,19 \%, \mathrm{TiO}_{2}=0,01-1,06 \%, \mathrm{P}_{2} \mathrm{O}_{5}=0,05-1,39 \%$ dII. CRM yang digunakan untuk data perhitungan ketidakpastian adalah NCS DC 73312a dan NCS DC 73313a. Total unsur oksida yang diuji dalam aplikasi/program sedimen sungai adalah 24 unsur oksida dan hilang pijar (HP).

Perhitungan nilai ketidakpastian hilang pijar (HP) ditetapkan dengan menggunakan metode gravimetri dan dibuat perhitungan tersendiri, karena dalam aplikasi pengujian kadar HP dimasukkan ketika pengujian akan dilakukan.

Tahapan preparasi percontoh meliputi pemanasan serbuk CRM dalam oven selama lebih kurang 2 jam pada suhu antara $105-110^{\circ} \mathrm{C}$, didiamkan selama 30 menit dalam desikator. Penimbangan flux $\mathrm{LiBO}_{2}$ sebanyak 5,0000 gram dan selanjutnya dilakukan penimbangan CRM sebanyak 1,0000 gram, kemudian kedua bahan tersebut dicampurkan dalam cawan platina dan dilakukan peleburan sampai CRM/percontoh melebur sempurna dan membentuk larutan yang transparan bening, dicetak dalam cetakan platina dan didinginkan, kemudian diradiasi dengan sinar-X yang dihasilkan dari anoda rhodium pada alat XRF.

Sebelum dilakukan penentuan ketidakpastian dalam suatu metode pengujian atau pengukuran, sebelumnya harus didata terlebih dahulu faktor apa saja yang menyebabkan terjadinya kesalahan dalam metode pengujian tersebut, selanjutnya dibuat diagram tulang ikan. Dalam menentukan ketidakpastian pengujian sedimen sungai dengan teknik XRF spektrometri digambarkan dengan diagram tulang ikan seperti Gambar 1.

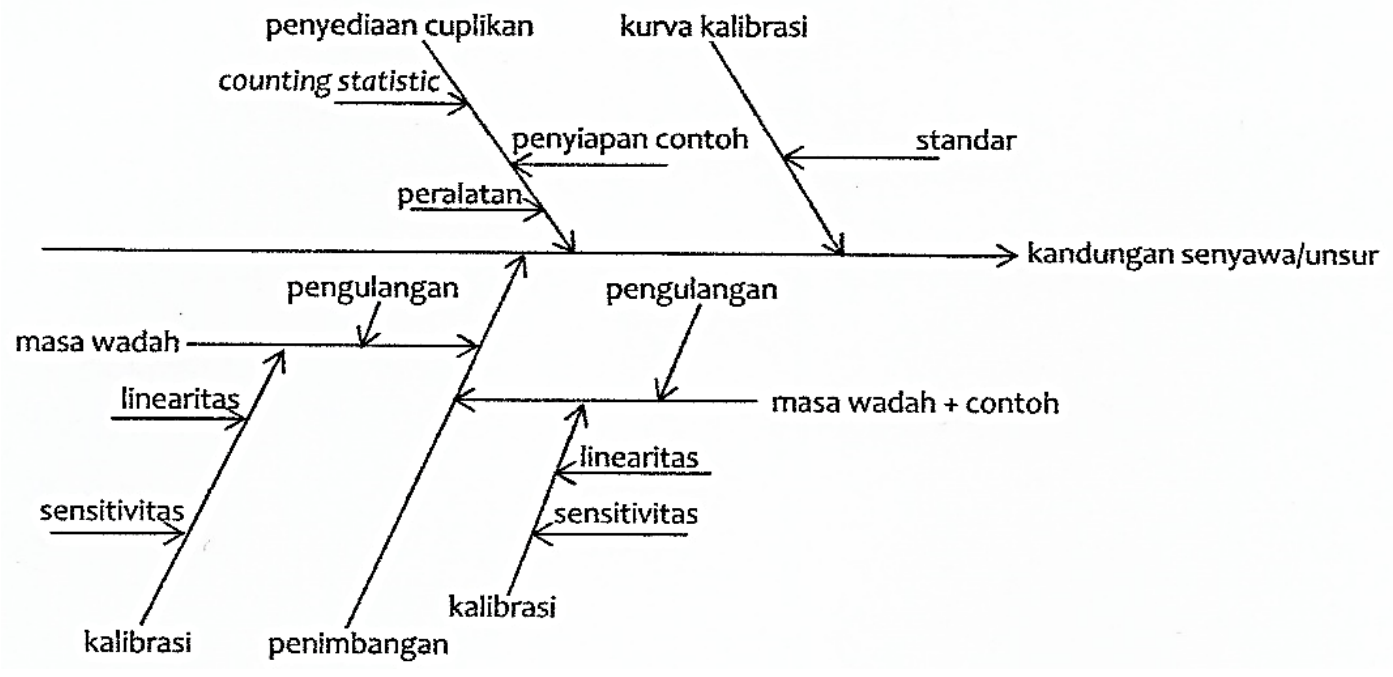

Gambar 1. Diagram tulang ikan pengujian XRF 
Pengelompokkan faktor-faktor kesalahan ke dalam kategori komponen ketidakpastian apakah termasuk tipe A atau B. Tipe A, berdasarkan pekerjaan ekperimental dan dihitung dari rangkaian pengamatan berulang yang selanjutnya estimasi masing-masing kompenen ketidakpastian sehingga ekivalen dengan sebuah simpangan baku (s) yang disebut sebagai ketidakpastian baku $(\mu)$, tipe $A$ adalah $\mu=s / \sqrt{ }$ n. Tipe $B$ diperoleh dengan cara selain analisis statistik dari serangkaian pengamatan yang biasanya didasarkan pada justifikasi ilmiah menggunakan semua informasi relevan yang tersedia, yang dapat meliputi: data pengukuran sebelumnya, pengalaman dengan atau pengetahuan umum tentang tingkah laku dan sifat instrumen dan bahan yang relevan, spesifikasi pabrik, data yang diberikan dalam sertifikat atau laporan lainnya, ketidakpastian yang diberikan untuk data acuan yang diambil dari data book. Distribusi kemungkinan: rectangular, ketidakpastian baku diperoleh dengan membagi semi-range ' $a$ ' dengan $\sqrt{ } 3$, yaitu $\mu=a / \sqrt{ } 3$. Distribusi kemungkinan triangular, digunakan bila terdapat bukti bahwa nilai yang paling mungkin adalah nilai yang dekat dengan nilai rata-rata, lebih dekat dengan batas rentang, kemungkinan menuju nol. Ketidakpastian baku diperoleh dengan membagi semi-range ' $a$ ' dengan $\sqrt{6}$, yaitu $\mu=a / \sqrt{ } 6$. Distribusi kemungkinan bentuk-U. Distribusi ini terjadi di beberapa bidang metrologi, ketidakpastian diperoleh dengan semi-range ' $a$ ' dengan $\sqrt{ } 2$, yaitu $\mu=\mathrm{a} / \sqrt{ } 2$. Distribusi Gaussian atau normal. Distribusi ini dapat digunakan bila-diasumsikan untuk ketidakpastian yang menyatakan tingkat kepercayaan tertentu, 95\% atau 99\%. Ketidakpastian baku diperoleh dengan membagi ketidakpastian tersebut dengan faktor cakupan yang tepat berdasarkan tabel distribusi-t, yaitu $\mu=U / k$. $U$ adalah ketidakpastian bentangan untuk tingkat kepercayaan tertentu dan $\mathrm{k}$ adalah faktor cakupan (KAN, 2002; Sukirno dan Taftazani, 2010; Sukirno dkk., 2015; Setiati, 2018).

Perhitungan ketidakpastian baku linearitas timbangan yang diperoleh dari sertifikat adalah $\mu=\mathrm{a} / \sqrt{3}$, karena dalam penentuan linearitas proses ini melibatkan penimbangan dua objek yang berbeda yaitu $m_{\text {tare }}$ dan $m_{\text {gross, }}$ maka kontribusi ketidakpastian baku linearitas timbangan terhadap ketidakpastian baku penimbangan $\mu_{2}=\sqrt{2} \times \mu$. Perhitungan pengulangan timbangan adalah: ( $\left.m_{\text {gross }}-m_{\text {tare }}\right)$ dengan ketidakpastian baku pengulangan dihitung dengan $\mu_{3}=s / \sqrt{ } 3$, dan untuk perhitungan ketidakpastian baku gabungan adalah upenimbangan $=\sqrt{ }\left(\mathrm{u}_{2}{ }^{2}+\mathrm{u}_{3}{ }^{2}\right)$.

Pengerjaan penyiapan percontoh di laboratorium meliputi penimbangan, pencampuran dengan zat pelebur, peleburan dan pengamatan/ perekaman intensitas pada waktu radiasi sinar-X. Pada tahap penyiapan cuplikan percontoh dan perekaman intensitas cuplikan unsur-unsur akan terjadi kesalahan-kesalahan berikut:

(1) Kesalahan penyiapan cuplikan (sample preparation error);

(2) Kesalahan peralatan (instrumentation error), misalnya karena alat belum stabil;

(3) Kesalahan pencacahan (counting statistic error), hanya tergantung dari waktu lamanya pengukuran intensitas;

(4) Kesalahan total yakni jumlah keseluruhan dari ketiga kesalahan di atas.

Untuk menghitung/mengukur kesalahankesalahan di atas, dibuat 2 percobaan. Percobaan pertama, disiapkan 10 cuplikan dari percontoh yang sama ialah NCS DC 73312a. Setiap cuplikan diamati intensitas $\mathrm{SiO}_{2}, \mathrm{Al}_{2} \mathrm{O}_{3}, \mathrm{Fe}_{2} \mathrm{O}_{3}, \mathrm{MnO}, \mathrm{MgO}$, $\mathrm{CaO}, \mathrm{Na}_{2} \mathrm{O}, \mathrm{K}_{2} \mathrm{O}, \mathrm{TiO}_{2}$, dan $\mathrm{P}_{2} \mathrm{O}_{5}$, dll. Pada percobaan pertama ini terdapat tiga jenis kesalahan, yakni kesalahan penyiapan percontoh $\left(E_{s p}\right)$, kesalahan peralatan (Eins) dan kesalahan pencacahan $\left(E_{c s}\right)$. Kesalahan Total $\left(E_{11}\right)$ dari ketiga kesalahan ini akan mengikuti hukum propagasi yakni: $\left(\mathrm{E}_{\mathrm{T} 1}\right)^{2}=\left(\mathrm{E}_{\mathrm{sp}}\right)^{2}+\left(\mathrm{E}_{\mathrm{ins}}\right)^{2}+\left(\mathrm{E}_{\mathrm{cs}}\right)^{2}$.

Percobaan kedua. Salah satu dari cuplikan di atas diamati intensitas $\mathrm{SiO}_{2}, \mathrm{Al}_{2} \mathrm{O}_{3}, \mathrm{Fe}_{2} \mathrm{O}_{3}, \mathrm{MnO}$, $\mathrm{MgO}, \mathrm{CaO}, \mathrm{Na}_{2} \mathrm{O}, \mathrm{K}_{2} \mathrm{O}, \mathrm{TiO}_{2}$, dan $\mathrm{P}_{2} \mathrm{O}_{5}$, dll. sebanyak 10 kali. Percobaan ini hanya akan memiliki dua kesalahan yakni, kesalahan peralatan (Eins) dan kesalahan pencacahan $\left(E_{c s}\right)$. Kesalahan Total (Ет2) dari kedua kesalahan ini akan mengikuti hukum propagasi yakni: $\left(\mathrm{E}_{\mathrm{T} 2}\right)^{2}=$ $\left(E_{i n s}\right)^{2}+\left(E_{c s}\right)^{2}$. Kesalahan total dihitung dengan rumus: $(\mathrm{ET})=\sqrt{\left[\sum(\mathrm{R}-\overline{\mathrm{R}})^{2} /(\mathrm{n}-1)\right]} / \overline{\mathrm{R}} . \mathrm{R}$ ialah intensitas, $\overline{\mathrm{R}}$ ialah harga rata-rata intensitas sedangkan (n-1) ialah harga derajat kebebasan 
(degree of freedom). Sedangkan besarnya kesalahan pencacahan $\left(\mathrm{E}_{\mathrm{cs}}\right)$ dapat dihitung dengan rumus: $(E C S)=1 / \sqrt{(\overline{\mathrm{R}} \times \mathrm{t})}$. $\mathrm{t}$ ialah waktu radiasi dalam detik sedangkan $\overline{\mathrm{R}}$ dinyatakan dalam count per second (cps). Dengan mensubstitusikan harga $\mathrm{E}_{\text {cs }}$ pada persamaan $\left(\mathrm{E}_{\mathrm{T} 2}\right)^{2}$ $=\left(E_{i n s}\right)^{2}+\left(E_{c s}\right)^{2}$, nilai kesalahan $E_{i n s}$ dapat dihitung. Nilai kesalahan Esp dihitung dari persamaan $\left(\mathrm{E}_{\mathrm{T} 1}\right)^{2}=\left(\mathrm{E}_{\mathrm{sp}}\right)^{2}+\left(\mathrm{E}_{\mathrm{ins}}\right)^{2}+\left(\mathrm{E}_{\mathrm{cs}}\right)^{2}$ (Rousseau, 2001; Sumadi dan Rohayati, 2003).

\section{Ketidakpastian Baku Gabungan}

Ketidakpastian baku gabungan dari suatu pengukuran, dinotasikan dengan $\mu_{\mathrm{c}}(\mathrm{y})$, diambil untuk mewakili taksiran simpangan baku (estimated standard deviation) dari hasil pengukuran yang diperoleh dengan menggabungkan ketidakpastian baku dari setiap taksiran masukan berdasarkan pendekatan deret Taylor orde satu dari model pengukuran. Metode penggabungan ketidakpastian baku ini sering disebut dengan hukum propagasi ketidakpastian. Ketidakpastian baku pada kurva kalibrasi (s) dihitung dengan rumus, $s=\sqrt{ }(S S R / v)$. SSR $=$ jumlah kuadrat residual dan $\mathrm{v}=$ derajat kebebasan (KAN, 2002).

Untuk pengukuran yang telah dikarakterisasi dengan baik di bawah pengendalian statistik, simpangan baku pooled $S_{p}$, dengan derajat kebebasan $v_{p}$ berdasarkan $M$ seri pengamatan terhadap variabel yang sama dapat tersedia. Simpangan baku pooled ditentukan oleh: $\mathrm{S}_{\mathrm{p}}=$ $\sqrt{\Sigma} v_{p} \times S_{i} / \Sigma v_{i}, v_{p}=\Sigma v_{i}$. Si adalah simpangan baku eksperimental dari satu seri $m_{i}$ pengamatan berulang yang saling bebas dan mempunyai derajat kebebasan: $v_{1}=m_{i}-1 \quad(K A N, 2002$; Sumadi dan Rohayati, 2003).

\section{HASIL DAN PEMBAHASAN}

Timbangan analitik yang digunakan ialah timbangan 4 desimal METTLER, tipe single pan AE-100 yang telah dikalibrasi oleh Pusat Penelitian dan Pengembangan Teknologi Minyak dan Gas Bumi (Lemigas) tanggal 18 Oktober 2017 dengan No. Sertifikat: SK-4518 (Lemigas, 2017). Harga penyimpangan penimbangan dari nilai beban nominal $5 \mathrm{~g}=0,08 \mathrm{mg}$ pada tingkat kepercayaan $95 \%$ dengan faktor cakupan $\mathrm{k}=$ 2,0. Ketidakpastian baku linearitas timbangan adalah $\mu=0,0462 \mathrm{mg}$. Karena dalam penentuan linearitas proses ini melibatkan penimbangan dua objek yang berbeda yaitu mtare dan $m_{\text {gross, }}$ maka kontribusi ketidakpastian baku linearitas timbangan terhadap ketidakpastian baku penimbangan $\mu_{2}=0,0653 \mathrm{mg}$.

Pengulangan timbangan dievaluasi dengan melakukan penimbangan $m_{\text {tare }}$ dan $m_{\text {gross }}$ secara berurutan, sebanyak $10 \mathrm{kali}$, sehingga diperoleh sepuluh nilai residual seperti terlihat pada Tabel 1. Simpangan baku residual dari sepuluh kali penimbangan ialah $5,164 \times 10^{-5}$, ketidakpastian baku dari pengulangan $\mathrm{u}_{3}=5,164 \times 10^{-5} / \sqrt{3}=$ $2,981 \times 10^{-5}$. Ketidakpastian baku gabungan adalah : Upenimbangan $=\sqrt{ }\left(5,954 \times 10^{-10}+3,312 \times\right.$ $\left.10^{-10}\right)=3,044 \times 10^{-5} \mathrm{~g}$.

Tabel 1. Pengulangan penimbangan mtare dan $m_{\text {gross }}$

\begin{tabular}{cccc}
\hline No. & mtare & m gross & Residual \\
\hline 1 & 11,6995 & 12,6994 & 0,9999 \\
2 & 11,6994 & 12,6993 & 0,9999 \\
3 & 11,6995 & 12,6995 & 1,0000 \\
4 & 11,6995 & 12,6994 & 0,9999 \\
5 & 11,6995 & 12,6995 & 1,0000 \\
6 & 11,6996 & 12,6995 & 0,9999 \\
7 & 11,6996 & 12,6995 & 0,9999 \\
8 & 11,6995 & 12,6995 & 1,0000 \\
9 & 11,6995 & 12,6995 & 1,0000 \\
10 & 11,6994 & 12,6993 & 0,9999 \\
\hline
\end{tabular}

Kesalahan total penyediaan percontoh untuk senyawa/unsur yang dianalisis ditabulasikan pada Tabel 2 yang menggambarkan kesalahan penyiapan cuplikan percontoh standar yang terdiri dari penyediaan percontoh, kesalahan counting statistic dan kesalahan instrumen dari percontoh uji CRM NCS DC 73312a dan NCS DC 73313a dengan mempergunakan aplikasi pengujian sedimen sungai.

Dua percobaan telah dilakukan pada CRM NCS DC 73312a dan NCS DC 73313a, percobaan pertama disiapkan 10 cuplikan CRM kemudian diukur intensitas untuk masing-masing unsur oksida yang diamati $\mathrm{SiO}_{2}, \mathrm{Al}_{2} \mathrm{O}_{3}, \mathrm{Fe}_{2} \mathrm{O}_{3}, \mathrm{TiO}_{2}$, $\mathrm{MgO}, \mathrm{CaO}, \mathrm{Na}_{2} \mathrm{O}, \mathrm{K}_{2} \mathrm{O}, \mathrm{P}_{2} \mathrm{O}_{5}, \mathrm{MnO}, \mathrm{As}_{2} \mathrm{O}_{3}$, 
$\mathrm{BaO}, \mathrm{CeO}_{2}, \mathrm{Cr}_{2} \mathrm{O}_{3}, \mathrm{CuO}, \mathrm{NiO}, \mathrm{PbO}, \mathrm{Rb}_{2} \mathrm{O}, \mathrm{SO}_{3}$, $\mathrm{SrO}, \mathrm{V}_{2} \mathrm{O}_{5}, \mathrm{Y}_{2} \mathrm{O}_{3}, \mathrm{ZnO}$ dan $\mathrm{ZrO}_{2}$. Percobaan kedua, salah satu cuplikan percobaan pertama diukur intensitas unsur-unsur yang diamati tadi sebanyak 10 kali. Pada setiap pengukuran percontoh dikeluarkan dari dan ditempatkan kembali ke sample holder.

Ketidakpastian baku komponen yang memengaruhi penyedian cuplikan percontoh, menggunakan CRM NCS DC 73312a dan NCS DC 73313a, sebagai ilustrasi percontoh untuk kandungan $\mathrm{SiO}_{2}$ dan $\mathrm{Al}_{2} \mathrm{O}_{3}$, sebagaimana pada
Tabel 3 dan 4 menunjukkan ketidakpastian baku gabungan penyediaan cuplikan percontoh (China National Analysis Center for Iron dan Steel, 2010).

Ketidakpastian baku gabungan dari CRM NCS DC 73312a dan NCS DC 73313a yang dianalisis, dihitung dengan formula untuk simpangan baku pooled (Sp). Setiap unsur yang diamati dianalisis masing-masing 10 kali pengamatan dari cuplikan yang berbeda dan saling bebas, seperti terlihat pada Tabel 5.

Tabel 2. Kesalahan penyiapan cuplikan percontoh CRM sedimen sungai

\begin{tabular}{|c|c|c|c|c|c|c|c|c|c|}
\hline \multirow{2}{*}{ CRM } & \multirow{2}{*}{ Parameter } & \multicolumn{8}{|c|}{ Unsur yang dianalisis } \\
\hline & & $\mathrm{SiO}_{2}$ & $\mathrm{Al}_{2} \mathrm{O}_{3}$ & $\mathrm{Fe}_{2} \mathrm{O}_{3}$ & $\mathrm{MnO}$ & $\mathrm{MgO}$ & $\mathrm{CaO}$ & $\mathrm{Na}_{2} \mathrm{O}$ & $\mathrm{K}_{2} \mathrm{O}$ \\
\hline \multirow{14}{*}{$\begin{array}{l}\text { NCS DC } \\
73312 a\end{array}$} & $\mathrm{E}_{\mathrm{CS}}$ & 0,0002 & 0,0006 & 0,0005 & 0,0040 & 0,0086 & 0,0028 & 0,0036 & 0,0004 \\
\hline & Eins & 0,0009 & 0,0004 & 0,0010 & 0,0116 & 0,0275 & 0,0063 & 0,0034 & 0,0009 \\
\hline & $\mathrm{E}_{\mathrm{sp}}$ & 0,0006 & 0,0071 & 0,0404 & 0,0086 & 0,2291 & 0,0525 & 0,0106 & 0,0064 \\
\hline & ET1 & 0,0058 & 0,0071 & 0,0404 & 0,0088 & 0,2308 & 0,0530 & 0,0117 & 0,0065 \\
\hline & & $\mathrm{TiO}_{2}$ & $\mathrm{P}_{2} \mathrm{O}_{5}$ & $\mathrm{SO}_{3}$ & $\mathrm{As}_{2} \mathrm{O}_{3}$ & $\mathrm{BaO}$ & $\mathrm{CeO}_{2}$ & $\mathrm{Cr}_{2} \mathrm{O}_{3}$ & $\mathrm{CuO}$ \\
\hline & $\mathrm{E}_{\mathrm{cs}}$ & 0,0044 & 0,0088 & 0,0068 & 0,0070 & 0,0335 & 0,0298 & 0,0105 & 0,0072 \\
\hline & Eins & 0,0043 & 0,0231 & 0,0530 & 0,0440 & 0,2524 & 0,1631 & 0,0543 & 0,0521 \\
\hline & $E_{s p}$ & 0,0093 & 0,0222 & 0,1673 & 0,1141 & 0,0726 & 0,0234 & 0,0168 & 0,2278 \\
\hline & ET1 & 0,0112 & 0,0332 & 0,1757 & 0,1225 & 0,1712 & 0,2866 & 0,0527 & 0,2338 \\
\hline & & $\mathrm{NiO}$ & $\mathrm{PbO}$ & $\mathrm{Rb}_{2} \mathrm{O}$ & $\mathrm{SrO}$ & $\mathrm{V}_{2} \mathrm{O}_{5}$ & $\mathrm{Y}_{2} \mathrm{O}_{3}$ & $\mathrm{ZnO}$ & $\mathrm{ZrO}_{2}$ \\
\hline & $\mathrm{E}_{\mathrm{cs}}$ & 0,0068 & 0,0058 & 0,0009 & 0,0042 & 0,0406 & 0,0017 & 0,0045 & 0,0116 \\
\hline & Eins & 0,0352 & 0,0551 & 0,0001 & 0,0642 & 0,4803 & 0,0069 & 0,0176 & 0,0476 \\
\hline & $E_{s p}$ & 0,7620 & 0,1253 & 0,0100 & 0,0582 & 0,2065 & 0,0115 & 0,0414 & 0,1555 \\
\hline & $\mathrm{ET}_{1}$ & 0,7628 & 0,1370 & 0,0102 & 0,0272 & 0,5243 & 0,0135 & 0,0453 & 0,1630 \\
\hline \multirow{15}{*}{$\begin{array}{l}\text { NCS DC } \\
73313 a\end{array}$} & & $\mathrm{SiO}_{2}$ & $\mathrm{Al}_{2} \mathrm{O}_{3}$ & $\mathrm{Fe}_{2} \mathrm{O}_{3}$ & $\mathrm{MnO}$ & $\mathrm{MgO}$ & $\mathrm{CaO}$ & $\mathrm{Na}_{2} \mathrm{O}$ & $\mathrm{K}_{2} \mathrm{O}$ \\
\hline & $\mathrm{E}_{\mathrm{cs}}$ & 0,0002 & 0,0006 & 0,0003 & 0,0021 & 0,0033 & 0,0013 & 0,0071 & 0,0005 \\
\hline & Eins & 0,0006 & 0,0008 & 0,0006 & 0,0017 & 0,0064 & 0,0014 & 0,0110 & 0,0002 \\
\hline & $E_{s p}$ & 0,0279 & 0,0382 & 0,0394 & 0,0291 & 0,0565 & 0,0647 & 0,0314 & 0,0271 \\
\hline & ET1 & 0,0279 & 0,0282 & 0,0394 & 0,0292 & 0,0570 & 0,0648 & 0,0340 & 0,0271 \\
\hline & & TiO2 & $\mathrm{P}_{2} \mathrm{O}_{5}$ & $\mathrm{SO}_{3}$ & $\mathrm{As}_{2} \mathrm{O}_{3}$ & $\mathrm{BaO}$ & $\mathrm{CeO}_{2}$ & $\mathrm{Cr}_{2} \mathrm{O}_{3}$ & $\mathrm{CuO}$ \\
\hline & $\mathrm{E}_{\mathrm{CS}}$ & 0,0021 & 0,0043 & 0,0038 & 0,0061 & 0,0133 & 0,0277 & 0,0089 & 0,0050 \\
\hline & Eins & 0,0011 & 0,0083 & 0,0154 & 0,0450 & 0,0289 & 0,1498 & 0,0265 & 0,0218 \\
\hline & $E_{s p}$ & 0,0304 & 0,0268 & 0,3875 & 0,1363 & 0,0291 & 0,1977 & 0,0433 & 0,2794 \\
\hline & $\mathrm{E}_{\mathrm{T} 1}$ & 0,0305 & 0,0284 & 0,3878 & 0,1437 & 0,0431 & 0,2496 & 0,0515 & 0,2803 \\
\hline & & $\mathrm{NiO}$ & $\mathrm{PbO}$ & $\mathrm{Rb}_{2} \mathrm{O}$ & $\mathrm{SrO}$ & $\mathrm{V}_{2} \mathrm{O}_{5}$ & $\mathrm{Y}_{2} \mathrm{O}_{3}$ & $\mathrm{ZnO}$ & $\mathrm{ZrO}_{2}$ \\
\hline & $\mathrm{E}_{\mathrm{cs}}$ & 0,0026 & 0,0048 & 0,0014 & 0,0019 & 0,0134 & 0,0022 & 0,0032 & 0,0088 \\
\hline & Eins & 0,0043 & 0,0334 & 0,0044 & 0,0125 & 0,0371 & 0,0132 & 0,0077 & 0,0188 \\
\hline & $\mathrm{E}_{\mathrm{sp}}$ & 0,7024 & 0,1923 & 0,0246 & 0,0081 & 0,0337 & 0,0070 & 0,0514 & 0,1873 \\
\hline & $\mathrm{E}_{\mathrm{T} 1}$ & 0,7024 & 0,1952 & 0,0250 & 0,0150 & 0,0519 & 0,0151 & 0,0521 & 0,1885 \\
\hline
\end{tabular}

Keterangan: $\mathrm{E}_{\mathrm{cs}}=$ Kesalahan counting statistic $\quad \mathrm{E}_{\mathrm{sp}}=$ Kesalahan penyediaan percontoh Eins $=$ Kesalahan instrumen $\quad \mathrm{E}_{\mathrm{T} 1}=$ Kesalahan total 
Tabel 3. Komponen ketidakpastian baku kandungan $\mathrm{SiO}_{2}$ dalam cuplikan percontoh CRM NCS DC 73312a dan NCS DC 73313a

\begin{tabular}{|c|c|c|c|c|c|}
\hline $\begin{array}{c}\text { Tanda } \\
\text { percontoh }\end{array}$ & Komponen & Ui & $\mathrm{Ci}(\%)$ & $\mathrm{Ui} \times \mathrm{Ci}$ & $(\mathrm{Ui} \times \mathrm{Ci}) 2$ \\
\hline \multirow{4}{*}{$\begin{array}{c}\text { NCS DC } \\
73312 \mathrm{a}\end{array}$} & $\mathrm{E}_{\mathrm{cs}}$ & 0,0002 & \multirow[t]{3}{*}{78,12} & 0,0001442 & $2,08 \times 10-8$ \\
\hline & Ein & 0,0009 & & 0,0006491 & $4,21 \times 10-7$ \\
\hline & $\mathrm{E}_{\mathrm{sp}}$ & 0,0006 & & 0,0004327 & $1,87 \times 10-7$ \\
\hline & \multicolumn{4}{|c|}{ Jumlah ketidakpastian gabungan } & $6,29 \times 10-7$ \\
\hline \multirow{4}{*}{$\begin{array}{c}\text { NCS DC } \\
73313 a\end{array}$} & $\mathrm{E}_{\mathrm{cs}}$ & 0,0002 & \multirow[t]{3}{*}{72,45} & 0,0001449 & $2,10 \times 10-8$ \\
\hline & Ein & 0,0006 & & 0,0004347 & $1,89 \times 10-7$ \\
\hline & $\mathrm{E}_{\mathrm{sp}}$ & 0,0279 & & 0,0202136 & $4,08 \times 10-4$ \\
\hline & \multicolumn{4}{|c|}{ Jumlah ketidakpastian gabungan } & 0,0004082 \\
\hline
\end{tabular}

Keterangan : $\mathrm{U}_{\mathrm{i}}=$ Faktor kesalahan $\quad \mathrm{C}_{\mathrm{i}}=$ Konsentrasi unsur berdasarkan sertifikat

Tabel 4. Ketidakpastian penyediaan cuplikan percontoh

\begin{tabular}{|c|c|c|c|c|}
\hline $\begin{array}{c}\text { Tanda } \\
\text { percontoh }\end{array}$ & Parameter & Kesalahan total cuplikan & $\begin{array}{c}\text { Konsentrasi } \\
(\%)\end{array}$ & $\begin{array}{l}\text { Ketidakpastian penyiapan cuplikan } \\
\text { (Uprepa) }\end{array}$ \\
\hline \multirow{24}{*}{$\begin{array}{l}\text { NCS DC } \\
73312 \mathrm{a}\end{array}$} & $\mathrm{SiO}_{2}$ & 0,0057467 & 78,12 & 0,0044893 \\
\hline & $\mathrm{Al}_{2} \mathrm{O}_{3}$ & 0,0070687 & 11,06 & 0,0007818 \\
\hline & $\mathrm{Fe}_{2} \mathrm{O}_{3}$ & 0,0404519 & 1,53 & 0,0006189 \\
\hline & $\mathrm{TiO}_{2}$ & 0,0111575 & 0,18 & 0,0000197 \\
\hline & $\mathrm{MgO}$ & 0,2308538 & 0,15 & 0,0003463 \\
\hline & $\mathrm{CaO}$ & 0,0529838 & 0,13 & 0,0000689 \\
\hline & $\mathrm{Na}_{2} \mathrm{O}$ & 0,0117046 & 0,49 & 0,0000574 \\
\hline & $\mathrm{K}_{2} \mathrm{O}$ & 0,0064878 & 5,34 & 0,0003465 \\
\hline & $\mathrm{P}_{2} \mathrm{O}_{5}$ & 0,0332458 & 0,028 & 0,0000091 \\
\hline & $\mathrm{MnO}$ & 0,0088338 & 0,028 & 0,0000025 \\
\hline & $\mathrm{As}_{2} \mathrm{O}_{3}$ & 0,1225240 & 0,001 & 0,0000011 \\
\hline & $\mathrm{BaO}$ & 0,1712495 & 0,013 & 0,0000216 \\
\hline & $\mathrm{CeO}_{2}$ & 0,2866465 & 0,013 & 0,0000373 \\
\hline & $\mathrm{Cr}_{2} \mathrm{O}_{3}$ & 0,0526840 & 0,004 & 0,0000019 \\
\hline & $\mathrm{CuO}$ & 0,2338083 & 0,001 & 0,0000012 \\
\hline & $\mathrm{NiO}$ & 0,7628569 & 0,001 & 0,0000046 \\
\hline & $\mathrm{PbO}$ & 0,1370130 & 0,004 & 0,0000052 \\
\hline & $\mathrm{Rb}_{2} \mathrm{O}$ & 0,0101551 & 0,045 & 0,0000046 \\
\hline & $\mathrm{SO}_{3}$ & 0,1756727 & 0,019 & 0,0000334 \\
\hline & $\mathrm{SrO}$ & 0,0272265 & 0,002 & 0,0000007 \\
\hline & $\mathrm{V}_{2} \mathrm{O}_{5}$ & 0,5243544 & 0,002 & 0,0000100 \\
\hline & $\mathrm{Y}_{2} \mathrm{O}_{3}$ & 0,0135126 & 0,003 & 0,0000004 \\
\hline & $\mathrm{ZnO}$ & 0,0452711 & 0,005 & 0,0000022 \\
\hline & $\mathrm{ZrO}_{2}$ & 0,1630381 & 0,019 & 0,0000313 \\
\hline \multirow{12}{*}{$\begin{array}{l}\text { NCS DC } \\
73312 \mathrm{a}\end{array}$} & $\mathrm{SiO}_{2}$ & 0,0273379 & 72,45 & 0,0198060 \\
\hline & $\mathrm{Al}_{2} \mathrm{O}_{3}$ & 0,0385104 & 12,45 & 0,0047950 \\
\hline & $\mathrm{Fe}_{2} \mathrm{O}_{3}$ & 0,0402924 & 4,72 & 0,0019020 \\
\hline & $\mathrm{TiO}_{2}$ & 0,0343776 & 0,72 & 0,0002470 \\
\hline & $\mathrm{MgO}$ & 0,0504025 & 0,72 & 0,0003630 \\
\hline & $\mathrm{CaO}$ & 0,0658880 & 0,44 & 0,0002900 \\
\hline & $\mathrm{Na}_{2} \mathrm{O}$ & 0,0377690 & 0,39 & 0,0001470 \\
\hline & $\mathrm{K}_{2} \mathrm{O}$ & 0,0259914 & 2,87 & 0,0007460 \\
\hline & $\mathrm{P}_{2} \mathrm{O}_{5}$ & 0,0286724 & 0,0976 & 0,0000280 \\
\hline & $\mathrm{MnO}$ & 0,0298140 & 0,1023 & 0,0000305 \\
\hline & $\mathrm{As}_{2} \mathrm{O}_{3}$ & 0,1407007 & 0,0022 & 0,0000031 \\
\hline & $\mathrm{BaO}$ & 0,0496936 & 0,0612 & 0,0000304 \\
\hline
\end{tabular}


Perhitungan Nilai Ketidakpastian pada Pengujian Sedimen Sungai dengan Teknik ... Yayah Rohayati

\begin{tabular}{|c|c|c|c|c|}
\hline $\begin{array}{c}\text { Tanda } \\
\text { percontoh }\end{array}$ & Parameter & Kesalahan total cuplikan & $\begin{array}{c}\text { Konsentrasi } \\
(\%)\end{array}$ & $\begin{array}{l}\text { Ketidakpastian penyiapan cuplikan } \\
\text { (Uprepa) }\end{array}$ \\
\hline & $\mathrm{CeO}_{2}$ & 0,1543778 & 0,0106 & 0,0000164 \\
\hline & $\mathrm{Cr}_{2} \mathrm{O}_{3}$ & 0,0430436 & 0,0070 & 0,0000030 \\
\hline & $\mathrm{CuO}$ & 0,2771519 & 0,0253 & 0,0000701 \\
\hline & $\mathrm{NiO}$ & 0,6951374 & 0,0025 & 0,0000174 \\
\hline & $\mathrm{PbO}$ & 0,1782326 & 0,0048 & 0,0000086 \\
\hline & $\mathrm{Rb}_{2} \mathrm{O}$ & 0,0233355 & 0,0167 & 0,0000039 \\
\hline & $\mathrm{SO}_{3}$ & 0,3749339 & 0,0001 & 0,0000004 \\
\hline & $\mathrm{SrO}$ & 0,0244479 & 0,0024 & 0,0000006 \\
\hline & $\mathrm{V}_{2} \mathrm{O}_{5}$ & 0,0436276 & 0,0132 & 0,0000058 \\
\hline & $\mathrm{Y}_{2} \mathrm{O}_{3}$ & 0,0178305 & 0,0037 & 0,0000007 \\
\hline & $\mathrm{ZnO}$ & 0,0585116 & 0,0127 & 0,0000074 \\
\hline & $\mathrm{ZrO}_{2}$ & 0,1819123 & 0,0382 & 0,0000695 \\
\hline
\end{tabular}

Tabel 5. Ketidakpastian baku gabungan dari CRM NCS DC 73312a dan NCS DC 73313a

\begin{tabular}{lcc}
\hline \multicolumn{1}{c}{ Parameter } & Simpangan baku pooled $(\mathrm{Sp})$ & Ketidakpastian baku gabungan (Upc) \\
\hline $\mathrm{SiO}_{2}$ & 0,110220 & 0,07794 \\
$\mathrm{Al}_{2} \mathrm{O}_{3}$ & 0,05280 & 0,03734 \\
$\mathrm{Fe}_{2} \mathrm{O}_{3}$ & 0,03550 & 0,02510 \\
$\mathrm{TiO}_{2}$ & 0,01155 & 0,00816 \\
$\mathrm{MgO}$ & 0,01883 & 0,01332 \\
$\mathrm{CaO}$ & 0,01341 & 0,00949 \\
$\mathrm{Na} 2 \mathrm{O}$ & 0,01018 & 0,00720 \\
$\mathrm{~K}_{2} \mathrm{O}$ & 0,02337 & 0,01653 \\
$\mathrm{P}_{2} \mathrm{O}_{5}$ & 0,00442 & 0,00312 \\
$\mathrm{MnO}$ & 0,00400 & 0,00283 \\
$\mathrm{As}{ }_{2} \mathrm{O}_{3}$ & 0,00141 & 0,00100 \\
$\mathrm{BaO}$ & 0,00500 & 0,00354 \\
$\mathrm{CeO}$ & 0,00387 \\
$\mathrm{Cr}_{2} \mathrm{O}_{3}$ & 0,00548 & 0,00112 \\
$\mathrm{CuO}$ & 0,00158 & 0,00421 \\
$\mathrm{NiO}$ & 0,00596 & 0,00250 \\
$\mathrm{PbO}_{\mathrm{Rb}} \mathrm{O}$ & 0,00354 & 0,00187 \\
$\mathrm{SO}$ & 0,00265 & 0,00150 \\
$\mathrm{SrO}$ & 0,00212 & 0,00276 \\
$\mathrm{~V}_{2} \mathrm{O}_{5}$ & 0,00390 & 0,00057 \\
$\mathrm{Y}_{2} \mathrm{O}_{3}$ & 0,00081 & 0,00200 \\
$\mathrm{ZnO}$ & 0,00283 & 0,00052 \\
$\mathrm{ZrO}$ & 0,00074 & 0,00150 \\
\hline & 0,00212 & 0,00500 \\
\hline
\end{tabular}

\section{Kurva Kalibrasi}

Analisis kandungan senyawa/unsur dalam percontoh dengan teknik XRF dilakukan dengan mensubstitusikan besaran yang diamati (setelah terlebih dulu dikoreksi) ke dalam kurva kalibrasi. Kurva kalibrasi ini dibuat dari percontoh standar yang sejenis dengan percontoh uji dan dilakukan penyediaan percontoh, pengamatan besaran serta penggunaan parameter-parameter alat sesuai dengan percontoh yang akan diuji, dengan menggunakan 10 jenis CRM dan masing masing-masing dibuat cuplikan CRM/standar dengan menggunakan metode peleburan (perbandingan 5:1), yaitu 5 bagian flux dan 1 bagian CRM/standar.

Kurva kalibrasi dalam teknik XRF linear antara kandungan senyawa (konsentrasi) terhadap intensitas bersih (net intensity) dalam kCps dapat 
juga antara measurement intensity (kCps) terhadap theoritical net intensity. Net intensity ialah pembacaan setelah dikoreksi dead time detector, koreksi background, koreksi alpha dan koreksi line overlap. Fluktuasi tegangan listrik dikoreksi dengan melakukan perbandingan terhadap cuplikan monitor. Kemudian dilakukan perhitungan ketidakpastian baku penarikan kurva kalibrasi (s) (Bertin, 1984; Sumadi, Gunawan dan Rohayati, 2004).

Tabel 6 merupakan perbandingan antara data kurva kalibrasi dengan data standar yang digunakan untuk membuat kurva kalibrasi (Govindaraju, 1989).

Tabel 6. Perbandingan data standar dan data perhitungan kurva kalibrasi

\begin{tabular}{|c|c|c|c|c|c|c|c|c|}
\hline \multirow{2}{*}{ Standar } & \multicolumn{2}{|c|}{$\mathrm{SiO}_{2}$} & \multicolumn{2}{|c|}{$\mathrm{Al}_{2} \mathrm{O}_{3}$} & \multicolumn{2}{|c|}{$\mathrm{Fe}_{2} \mathrm{O}_{3}$} & \multicolumn{2}{|c|}{$\mathrm{MgO}$} \\
\hline & Std & Kurva & Std & Kurva & Std & Kurva & Std & Kurva \\
\hline GSD-1 & 58,43 & 57,996 & 14,83 & 14,845 & 7,35 & 7,365 & 4,14 & 4,189 \\
\hline GSD-2 & 69,90 & 69,793 & 15,72 & 15,569 & 1,89 & 1,873 & 0,21 & 0,124 \\
\hline GSD-3 & 71,28 & 70,677 & 12,04 & 12,137 & 6,51 & 6,670 & 0,70 & 0,718 \\
\hline GSD-4 & 52,51 & 52,414 & 15,67 & 15,435 & 5,90 & 5,936 & 1,04 & 1,070 \\
\hline GSD-5 & 56,36 & 56,671 & 15,37 & 15,316 & 5,86 & 5,847 & 0,98 & 0,856 \\
\hline GSD-6 & 61,23 & 61,291 & 14,16 & 14,237 & 5,88 & 5,988 & 3,00 & 2,991 \\
\hline GSD-7 & 64,63 & 65,501 & 13,44 & 13,860 & 6,49 & 6,824 & 3,06 & 3,173 \\
\hline MA-N & 66,60 & 66,214 & 17,62 & 17,543 & 0,47 & 0,573 & 0,04 & 0,000 \\
\hline GXR-1 & 48,52 & 47,629 & 6,63 & 6,756 & 35,74 & 37,683 & 0,36 & 0,322 \\
\hline GXR-5 & 41,50 & 44,606 & 38,17 & 37,154 & 4,83 & 4,269 & 1,97 & 1,816 \\
\hline SSR & \multicolumn{2}{|c|}{1,502728} & \multicolumn{2}{|c|}{0,165871} & \multicolumn{2}{|c|}{0,531422} & \multicolumn{2}{|c|}{0,008253} \\
\hline $\mathrm{v}$ & \multicolumn{2}{|c|}{8} & \multicolumn{2}{|c|}{8} & \multicolumn{2}{|c|}{8} & \multicolumn{2}{|c|}{8} \\
\hline $\mathrm{s}$ & \multicolumn{2}{|c|}{1,22586} & \multicolumn{2}{|c|}{0,407272} & \multicolumn{2}{|c|}{0,728987} & \multicolumn{2}{|c|}{0,090845} \\
\hline \multirow{2}{*}{ Standar } & \multicolumn{2}{|c|}{$\mathrm{CaO}$} & \multicolumn{2}{|c|}{$\mathrm{Na}_{2} \mathrm{O}$} & \multicolumn{2}{|c|}{$\mathrm{K}_{2} \mathrm{O}$} & \multicolumn{2}{|c|}{$\mathrm{TiO}_{2}$} \\
\hline & Std & Kurva & Std & Kurva & Std & Kurva & Std & Kurva \\
\hline GSD-1 & 4,60 & 4,645 & 3,50 & 3,569 & 2,77 & 2,744 & 0,98 & 0,976 \\
\hline GSD-2 & 0,25 & 0,329 & 3,04 & 3,075 & 5,19 & 5,166 & 0,23 & 0,210 \\
\hline GSD-3 & 0,22 & 0,346 & 0,32 & 0,363 & 2,46 & 2,528 & 1,06 & 1,098 \\
\hline GSD-4 & 7,52 & 7,540 & 0,30 & 0,427 & 2,23 & 2,283 & 0,89 & 0,903 \\
\hline GSD-5 & 5,34 & 5,360 & 0,40 & 0,277 & 2,10 & 2,121 & 0,90 & 0,890 \\
\hline GSD-6 & 3,87 & 3,902 & 2,31 & 2,274 & 2,44 & 2,373 & 0,78 & 0,754 \\
\hline GSD-7 & 1,66 & 1,790 & 1,12 & 1,104 & 3,55 & 3,799 & 0,75 & 0,790 \\
\hline MA-N & 0,59 & 0,694 & 5,84 & 5,897 & 3,18 & 3,245 & 0,01 & 0,000 \\
\hline GXR-1 & 1,34 & 1,345 & 0,07 & 0,016 & 0,06 & 0,000 & 0,06 & 0,039 \\
\hline GXR-5 & 1,18 & 1,074 & 1,05 & 0,898 & 1,06 & 0,899 & 0,37 & 0,348 \\
\hline SSR & \multicolumn{2}{|c|}{0,008105} & & & 0,0 & 653 & 0,0 & 682 \\
\hline $\mathrm{v}$ & & & & & & & & \\
\hline $\mathrm{s}$ & & 030 & & & 0,1 & 846 & 0,0 & 119 \\
\hline Standar & & & & & & & & \\
\hline standar & Std & Kurva & Std & Kurva & Std & Kurva & Std & Kurva \\
\hline GSD-1 & 0,34 & 0,336 & 0,12 & 0,122 & 0,0003 & 0,0007 & 0,1061 & 0,1005 \\
\hline GSD-2 & 0,05 & 0,070 & 0,03 & 0,031 & 0,0008 & 0,0042 & 0,0207 & 0,0223 \\
\hline GSD-3 & 0,14 & 0,158 & 0,05 & 0,053 & 0,0024 & 0,0022 & 0,0687 & 0,0648 \\
\hline GSD-4 & 0,11 & 0,123 & 0,11 & 0,109 & 0,0026 & 0,0021 & 0,0525 & 0,0458 \\
\hline GSD-5 & 0,14 & 0,152 & 0,15 & 0,153 & 0,0099 & 0,0051 & 0,0491 & 0,0458 \\
\hline GSD-6 & 0,23 & 0,234 & 0,13 & 0,126 & 0,0018 & 0,0040 & 0,0368 & 0,0344 \\
\hline GSD-7 & 0,19 & 0,201 & 0,09 & 0,038 & 0,0111 & 0,0086 & 0,0804 & 0,0886 \\
\hline MA-N & 1,39 & 1,251 & 0,04 & 0,095 & 0,0017 & 0,0010 & 0,0047 & 0,0139 \\
\hline GXR-1 & 0,15 & 0,168 & 0,11 & 0,123 & 0,0033 & 0,0275 & 0,2501 & 0,0878 \\
\hline GXR-5 & 0,07 & 0,090 & 0,04 & 0,032 & 0,0015 & 0,0008 & 0,2233 & 0,2399 \\
\hline SSR & & 658 & & 56 & 0,00 & 7909 & 0,00 & 5993 \\
\hline
\end{tabular}


Perhitungan Nilai Ketidakpastian pada Pengujian Sedimen Sungai dengan Teknik ... Yayah Rohayati

\begin{tabular}{|c|c|c|c|c|c|c|c|c|}
\hline \multirow{2}{*}{ Standar } & $\mathrm{P}_{2} \mathrm{O}_{5}$ & $\mathrm{MnO}$ & $\mathrm{As}_{2} \mathrm{O}_{3}$ & $\mathrm{BaO}$ & Standar & $\mathrm{P}_{2} \mathrm{O}_{5}$ & $\mathrm{MnO}$ & $\mathrm{As}_{2} \mathrm{O}_{3}$ \\
\hline & Std & Kurva & Std & Kurva & & Std & Kurva & Std \\
\hline $\mathrm{v}$ & \multicolumn{2}{|c|}{8} & \multicolumn{2}{|c|}{8} & \multicolumn{2}{|c|}{8} & \multicolumn{2}{|c|}{8} \\
\hline s & \multicolumn{2}{|c|}{0,051555} & \multicolumn{2}{|c|}{0,027500} & \multicolumn{2}{|c|}{0,00889308} & \multicolumn{2}{|c|}{0,05796487} \\
\hline \multirow{2}{*}{ Standar } & \multicolumn{2}{|c|}{$\mathrm{CeO}_{2}$} & \multicolumn{2}{|c|}{$\mathrm{Cr}_{2} \mathrm{O}_{3}$} & \multicolumn{2}{|c|}{$\mathrm{CuO}$} & \multicolumn{2}{|c|}{$\mathrm{NiO}$} \\
\hline & Std & Kurva & Std & Kurva & Std & Kurva & Std & Kurva \\
\hline GSD-1 & 0,0099 & 0,0124 & 0,0284 & 0,0275 & 0,0027 & 0,0041 & 0,0097 & 0,0077 \\
\hline GSD-2 & 0,0236 & 0,0223 & 0,0025 & 0,0022 & 0,0014 & 0,0170 & 0,0008 & 0,0025 \\
\hline GSD-3 & 0,0079 & 0,0095 & 0,0127 & 0,0141 & 0,0220 & 0,0132 & 0,0033 & 0,0019 \\
\hline GSD-4 & 0,0096 & 0,0107 & 0,0118 & 0,0127 & 0,0047 & 0,0032 & 0,0051 & 0,0051 \\
\hline GSD-5 & 0,0109 & 0,0138 & 0,0102 & 0,0100 & 0,0171 & 0,0135 & 0,0043 & 0,0042 \\
\hline GSD-6 & 0,0084 & 0,0000 & 0,0278 & 0,0291 & 0,0479 & 0,0492 & 0,0099 & 0,0105 \\
\hline GSD-7 & 0,0096 & 0,0184 & 0,0178 & 0,0194 & 0,0048 & 0,0016 & 0,0067 & 0,0045 \\
\hline MA-N & 0,0001 & 0,0000 & 0,0004 & 0,0012 & 0,0175 & 0,0063 & 0,0004 & 0,0004 \\
\hline GXR-1 & 0,0021 & 0,0041 & 0,0018 & 0,0043 & 0,0095 & 0,1196 & 0,0052 & 0,0000 \\
\hline GXR-5 & 0,0048 & 0,0209 & 0,0148 & 0,0125 & 0,0443 & 0,0283 & 0,0095 & 0,0039 \\
\hline SSR & \multicolumn{2}{|c|}{0,00005387} & \multicolumn{2}{|c|}{0,00000249} & \multicolumn{2}{|c|}{0,00160672} & \multicolumn{2}{|c|}{0,00000912} \\
\hline $\mathrm{v}$ & \multicolumn{2}{|c|}{8} & \multicolumn{2}{|c|}{8} & & & & \\
\hline $\mathrm{s}$ & 0,00 & 3933 & 0,00 & 844 & 0,040 & 8393 & 0,00 & 1981 \\
\hline & & & & & & & & \\
\hline Standar & Std & Kurva & Std & Kurva & Std & Kurva & Std & Kurva \\
\hline GSD-1 & 0,0026 & 0,0017 & 0,0250 & 0,3022 & 0,0621 & 0,0623 & 0,0216 & 0,0222 \\
\hline GSD-2 & 0,0034 & 0,0060 & 0,0250 & 0,2834 & 0,0033 & 0,0027 & 0,0030 & 0,0033 \\
\hline GSD-3 & 0,0043 & 0,0036 & 0,0499 & 0,0932 & 0,0106 & 0,0109 & 0,0214 & 0,0226 \\
\hline GSD-4 & 0,0032 & 0,0037 & 0,0999 & 0,0833 & 0,0168 & 0,0167 & 0,0211 & 0,0217 \\
\hline GSD-5 & 0,0121 & 0,0072 & 0,0999 & 0,0760 & 0,0241 & 0,0236 & 0,0195 & 0,0191 \\
\hline GSD-6 & 0,0029 & 0,0060 & 0,1998 & 0,0757 & 0,0315 & 0,0312 & 0,0253 & 0,0227 \\
\hline GSD-7 & 0,0377 & 0,0118 & 0,0499 & 0,0569 & 0,0260 & 0,0279 & 0,0171 & 0,0186 \\
\hline MA-N & 0,0031 & 0,0018 & 0,0250 & 0,0473 & 0,0099 & 0,0100 & 0,0009 & 0,0007 \\
\hline GXR-1 & 0,0786 & 0,0370 & 0,6417 & 0,1795 & 0,0325 & 0,0362 & 0,0143 & 0,0109 \\
\hline GXR-5 & 0,0023 & 0,0015 & 0,0674 & 0,0397 & 0,0130 & 0,0114 & 0,0100 & 0,0092 \\
\hline SSR & 0,00 & 5696 & 0,04 & 4544 & 0,000 & 2592 & 0,000 & 2957 \\
\hline v & & & & & & & & \\
\hline $\mathrm{s}$ & 0,01 & 34175 & 0,21 & 9732 & 0,001 & 0040 & 0,001 & 19573 \\
\hline & & & & & & & & \\
\hline Standar & Std & Kurva & Std & Kurva & Std & Kurva & Std & Kurva \\
\hline GSD-1 & 0,0127 & 0,0120 & 0,0029 & 0,0030 & 0,0098 & 0,0112 & 0,0419 & 0,0452 \\
\hline GSD-2 & 0,0514 & 0,0515 & 0,0085 & 0,0085 & 0,0055 & 0,0064 & 0,0621 & 0,0489 \\
\hline GSD-3 & 0,0086 & 0,0080 & 0,0028 & 0,0028 & 0,0065 & 0,0061 & 0,0297 & 0,0296 \\
\hline GSD-4 & 0,0142 & 0,0140 & 0,0033 & 0,0034 & 0,0126 & 0,0123 & 0,0159 & 0,0764 \\
\hline GSD-5 & 0,0129 & 0,0124 & 0,0033 & 0,0030 & 0,0302 & 0,0293 & 0,0297 & 0,0227 \\
\hline GSD-6 & 0,0117 & 0,0107 & 0,0025 & 0,0026 & 0,0179 & 0,0175 & 0,0230 & 0,0161 \\
\hline GSD-7 & 0,0161 & 0,0171 & 0,0030 & 0,0029 & 0,0296 & 0,0299 & 0,0219 & 0,0241 \\
\hline MA-N & 0,3937 & 0,4259 & 0,0001 & 0,0338 & 0,0274 & 0,0268 & 0,0036 & 0,0000 \\
\hline GXR-1 & 0,0015 & 0,0000 & 0,0041 & 0,0004 & 0,0946 & 0,0995 & 0,0051 & 0,0126 \\
\hline GXR-5 & 0,0045 & 0,0028 & 0,0020 & 0,0016 & 0,0061 & 0,0060 & 0,0189 & 0,0350 \\
\hline SSR & 0,00 & 30634 & 0,00 & 3452 & 0,000 & 3557 & 0,000 & 34362 \\
\hline v & & & & & & & & \\
\hline $\mathrm{s}$ & 0,01 & 9540 & 0,01 & 7135 & 0,001 & 36129 & 0,023 & 6280 \\
\hline
\end{tabular}

Ketidakpastian kurva kalibrasi dihitung dari semua titik yang membentuk kurva kalibrasi dengan tabel konstribusi seperti tercantum pada Tabel 7.

\section{Ketidakpastian Gabungan}

Ketidakpastian gabungan dalam analisis batuan sedimen sungai ini merupakan jumlah setiap elemen ketidakpastian, yakni penimbangan, 
penyediaan cuplikan dan pembuatan kurva kalibrasi. Jumlah ketidakpastian gabungan ini, mengikuti hukum propagasi Tabel 8 .

Gambar 2 dan 3 menunjukkan grafik kontribusi ketidakpastian dalam analisis percontoh batuan untuk analisis $\mathrm{SiO}_{2}$ dan $\mathrm{Fe}_{2} \mathrm{O}_{3}$. Dari kedua gambar kontribusi ketidakpastian di atas, terlihat bahwa penyumbang nilai ketidakpastian terbanyak dalam proses pengujian dengan metode XRF adalah pada pembuatan kurva kalibrasi. Data untuk perhitungan ketidakpastian kurva kalibrasi adalah membandingkan data CRM (sertifikat) dengan data CRM hasil pengujian. Kesalahan pada pembuatan kurva kalibrasi bisa dipengaruhi oleh koreksi antar unsur yang bersama-sama dilakukan dalam satu aplikasi pengujian, dan dapat juga dari penimbangan CRM/percontoh, permukaan percontoh cuplikan tidak rata, percontoh kurang homogen serta kondisi aplikasi pengukuran (background setting, pulse height analyser (PHA) Setting, overlap setting) pada setiap unsur.

Tabel 7. Kontribusi ketidakpastian kurva kalibrasi

\begin{tabular}{lccccc}
\hline \multicolumn{1}{c}{ Senyawa } & $U_{s}$ & Pembagi & $U_{i}$ & $\sum(U i C i)$ & $U_{\text {kurva }}$ \\
\hline $\mathrm{SiO}_{2}$ & 1,225858 & 1,732051 & 0,70775 & 4,18252 & 2,0451 \\
$\mathrm{Al}_{2} \mathrm{O}_{3}$ & 0,407272 & 1,732051 & 0,23514 & 0,38480 & 0,6203 \\
$\mathrm{Fe}_{2} \mathrm{O}_{3}$ & 0,728987 & 1,732051 & 0,42088 & 0,34058 & 0,5836 \\
$\mathrm{TiO}_{2}$ & 0,026119 & 1,732051 & 0,01508 & 0,00091 & 0,0302 \\
$\mathrm{MgO}$ & 0,090845 & 1,732051 & 0,05245 & 0,00813 & 0,0902 \\
$\mathrm{CaO}$ & 0,090030 & 1,732051 & 0,05198 & 0,01381 & 0,1175 \\
$\mathrm{Na} 2 \mathrm{O}$ & 0,093610 & 1,732051 & 0,05405 & 0,00970 & 0,0985 \\
$\mathrm{~K} 2 \mathrm{O}$ & 0,116846 & 1,732051 & 0,06746 & 0,01689 & 0,1300 \\
$\mathrm{P}_{2} \mathrm{O}_{5}$ & 0,051555 & 1,732051 & 0,02977 & 0,00014 & 0,0118 \\
$\mathrm{MnO}$ & 0,027500 & 1,732051 & 0,01588 & 0,00084 & 0,0289 \\
$\mathrm{As}{ }_{2} \mathrm{O}_{3}$ & 0,008893 & 1,732051 & 0,00513 & 0,000002 & 0,0013 \\
$\mathrm{BaO}$ & 0,057965 & 1,732051 & 0,03347 & 0,000299 & 0,0173 \\
$\mathrm{CeO} 2$ & 0,007339 & 1,732051 & 0,00424 & 0,000004 & 0,0019 \\
$\mathrm{Cr}_{2} \mathrm{O}{ }_{3}$ & 0,001578 & 1,732051 & 0,00091 & 0,000001 & 0,0011 \\
$\mathrm{CuO}$ & 0,040084 & 1,732051 & 0,02314 & 0,000040 & 0,0063 \\
$\mathrm{NiO}$ & 0,003020 & 1,732051 & 0,00174 & 0,000001 & 0,0010 \\
$\mathrm{PbO}_{\mathrm{Rb}} \mathrm{O}$ & 0,017484 & 1,732051 & 0,01009 & 0,000015 & 0,0039 \\
$\mathrm{SO}{ }_{3}$ & 0,011430 & 1,732051 & 0,00660 & 0,000035 & 0,0059 \\
$\mathrm{SrO}$ & 0,216990 & 1,732051 & 0,12528 & 0,001608 & 0,0401 \\
$\mathrm{~V}_{2} \mathrm{O}_{5}$ & 0,001610 & 1,732051 & 0,00093 & 0,000002 & 0,0015 \\
$\mathrm{Y}{ }_{2} \mathrm{O}_{3}$ & 0,001720 & 1,732051 & 0,00099 & 0,000002 & 0,0015 \\
$\mathrm{ZnO}$ & 0,011977 & 1,732051 & 0,00692 & 0,000002 & 0,0015 \\
$\mathrm{ZrO} 2$ & 0,001886 & 1,732051 & 0,00109 & 0,000003 & 0,0016 \\
\hline & 0,023116 & 1,732051 & 0,01335 & 0,000034 & 0,0058 \\
\hline
\end{tabular}

Tabel 8. Ketidakpastian analisis percontoh stream batuan (sedimen) dengan teknik XRF.

\begin{tabular}{lcccc}
\hline \multicolumn{1}{c}{ Parameter } & $\begin{array}{c}\text { Penimbangan } \\
\left(\mu_{\mathrm{p}}\right)\end{array}$ & $\begin{array}{c}\text { Penyediaan Cuplikan } \\
\left(\mu_{\mathrm{pc}}\right)\end{array}$ & $\begin{array}{c}\text { Kurva Kalibrasi } \\
\left(\mu_{\mathrm{c}}\right)\end{array}$ & $\begin{array}{c}\mu \text { gab } \\
(\%)\end{array}$ \\
\hline $\mathrm{SiO}_{2}$ & 0,00007 & 0,07794 & 2.045 & 2,0466 \\
$\mathrm{Al}_{2} \mathrm{O}_{3}$ & 0,00007 & 0,03734 & 0.6203 & 0,6214 \\
$\mathrm{Fe}_{2} \mathrm{O}_{3}$ & 0,00007 & 0,02510 & 0.5836 & 0,5841 \\
$\mathrm{TiO}_{2}$ & 0,00007 & 0,00816 & 0.0302 & 0,0312 \\
$\mathrm{MgO}$ & 0,00007 & 0,01332 & 0.0902 & 0,0911 \\
$\mathrm{CaO}$ & 0,00007 & 0,00949 & 0.1175 & 0,1179 \\
$\mathrm{Na} 2 \mathrm{O}$ & 0,00007 & 0,00720 & 0.0985 & 0,0988 \\
$\mathrm{~K}_{2} \mathrm{O}$ & 0,00007 & 0,01653 & 0.1300 & 0,1310 \\
$\mathrm{P}_{2} \mathrm{O}$ & 0,00007 & 0,00312 & 0.0118 & 0,0122 \\
\hline
\end{tabular}




\begin{tabular}{lcccc}
\hline \multicolumn{1}{c}{ Parameter } & $\begin{array}{c}\text { Penimbangan } \\
\left(\mu_{\mathrm{p}}\right)\end{array}$ & $\begin{array}{c}\text { Penyediaan Cuplikan } \\
\left(\mu_{\mathrm{pc}}\right)\end{array}$ & $\begin{array}{c}\text { Kurva Kalibrasi } \\
\left(\mu_{\mathrm{c}}\right)\end{array}$ & $\begin{array}{c}\mu \text { gab } \\
(\%)\end{array}$ \\
\hline $\mathrm{MnO}$ & 0,00007 & 0,00283 & 0.0289 & 0,0291 \\
$\mathrm{As}_{2} \mathrm{O}_{3}$ & 0,00007 & 0,00100 & 0.0013 & 0,0017 \\
$\mathrm{BaO}$ & 0,00007 & 0,00354 & 0.0173 & 0,0176 \\
$\mathrm{CeO}_{2}$ & 0,00007 & 0,00387 & 0.0019 & 0,0043 \\
$\mathrm{Cr}_{2} \mathrm{O}_{3}$ & 0,00007 & 0,00112 & 0.0011 & 0,0016 \\
$\mathrm{CuO}$ & 0,00007 & 0,00421 & 0.0063 & 0,0076 \\
$\mathrm{NiO}$ & 0,00007 & 0,00250 & 0.0010 & 0,0027 \\
$\mathrm{PbO}$ & 0,00007 & 0,00187 & 0.0039 & 0,0043 \\
$\mathrm{Rb}$ & 0,00007 & 0,00150 & 0.0059 & 0,0061 \\
$\mathrm{SO}$ & 0,00007 & 0,00276 & 0.0401 & 0,0402 \\
$\mathrm{SrO}$ & 0,00007 & 0,00057 & 0.0015 & 0,0016 \\
$\mathrm{~V}_{2} \mathrm{O}_{5}$ & 0,00007 & 0,00200 & 0.0015 & 0,0025 \\
$\mathrm{Y}_{2} \mathrm{O}_{3}$ & 0,00007 & 0,00052 & 0.0015 & 0,0016 \\
$\mathrm{ZnO}_{\mathrm{ZrO}}$ & 0,00007 & 0,00150 & 0.0016 & 0,0022 \\
\hline
\end{tabular}

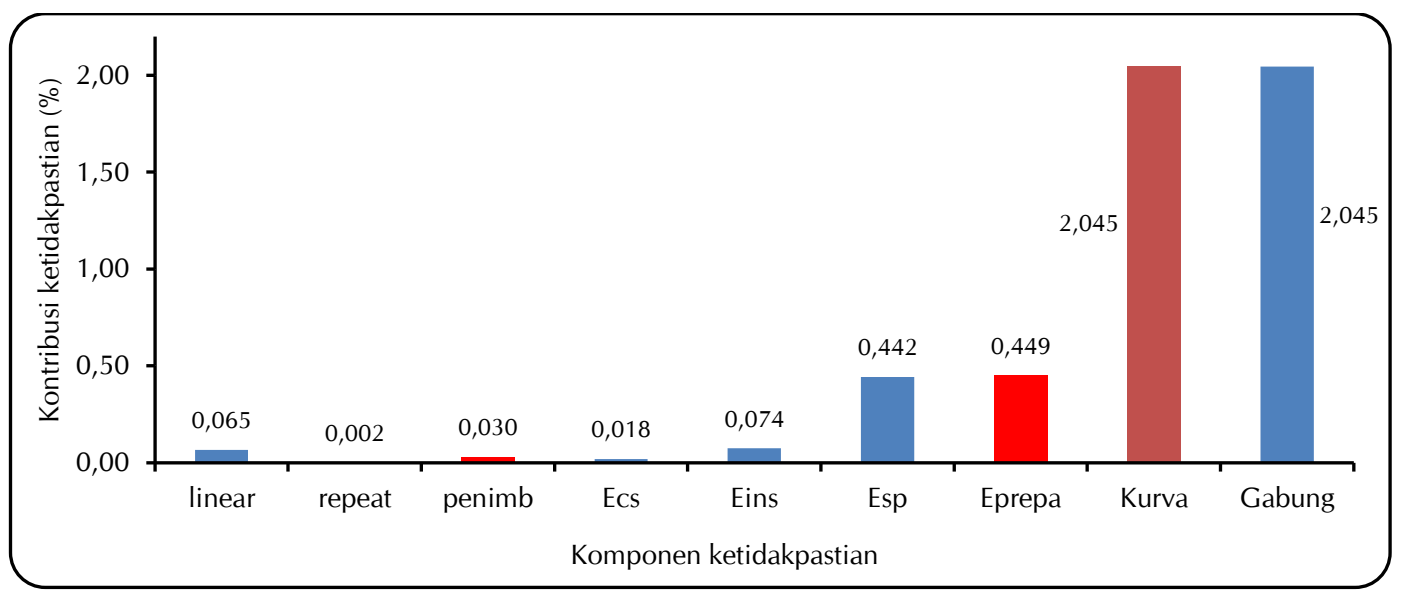

Gambar 2. Kontribusi ketidakpastian analisis $\mathrm{SiO}_{2}$ dalam percontoh batuan

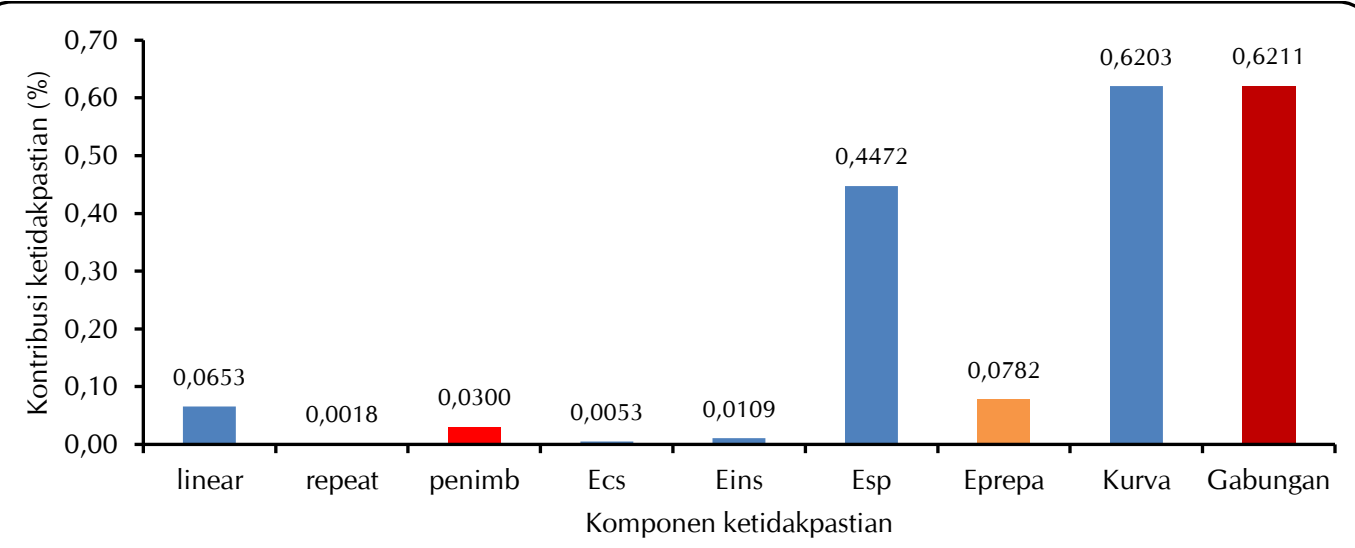

Gambar 3. Kontribusi ketidakpastian analisis $\mathrm{Fe}_{2} \mathrm{O}_{3}$ dalam percontoh batuan 
Untuk unsur-unsur dengan kadar rendah (part per million) kesalahan semakin besar kemungkinan dikarenakan pengenceran yang banyak yakni $5 x$, sehingga kesalahan semakin besar dan menyebabkan nilai ketidakpastian menjadi besar. Dalam preparasi pengujian dengan teknik XRF (1 cuplikan /CRM) dilakukan untuk semua unsur dalam satu kali pengukuran/aplikasi pengujian.

\section{KESIMPULAN DAN SARAN}

\section{Kesimpulan}

Dari hasil perhitungan nilai ketidakpastian pada pengujian sedimen sungai dengan teknik fluoresensi sinar-X (XRF), diperoleh nilai ketidakpastian gabungan sebagai berikut: kadar $\mathrm{SiO}_{2} 2,05 \%, \mathrm{Al}_{2} \mathrm{O}_{3} \mathrm{0}, 62 \%, \mathrm{Fe}_{2} \mathrm{O}_{3} \mathrm{0}, 58 \%, \mathrm{TiO}_{2}$ $0,031 \%, \mathrm{MgO} 0,091 \%, \mathrm{CaO} 0,12 \%, \mathrm{Na}_{2} \mathrm{O}$ $0,099 \%, \quad \mathrm{~K}_{2} \mathrm{O} \quad 0,13 \%, \mathrm{P}_{2} \mathrm{O}_{5} \quad 0,012 \%, \quad \mathrm{MnO}$ $0,029 \%, \mathrm{As}_{2} \mathrm{O}_{3} \mathrm{0}, 002 \%, \mathrm{BaO} 0,018 \%, \mathrm{CeO}_{2}$ $0,004 \%, \mathrm{Cr}_{2} \mathrm{O}_{3} \mathrm{0}, 002 \%, \mathrm{CuO} 0,008 \%, \mathrm{NiO}$ $0,003 \%, \mathrm{PbO} 0,004 \%, \mathrm{Rb}_{2} \mathrm{O} 0,006 \%, \mathrm{SO}_{3}$ $0,040 \%$, $\mathrm{SrO} 0,002 \%, \mathrm{~V}_{2} \mathrm{O}_{5} \quad 0,002 \%, \mathrm{Y}_{2} \mathrm{O}_{3}$ $0,002 \%, \mathrm{ZnO} 0,002 \%$ dan $\mathrm{ZrO}_{2}$ 0,008\%. Pada pelaporan hasil uji analisis rutin dengan menggunakan aplikasi pengujian sedimen sungai, nilai hasil perhitungan ketidakpastian pengukuran ini dapat dilaporkan sebagaimana dipersyaratkan dalam SNI/IEC 17025:2017.

Nilai ketidakpastian ini dapat digunakan untuk percontoh mineral oksida lainnya yang mempunyai data konsentrasi oksida hampir sama dan preparasi pembuatan cuplikan sama dengan cuplikan sedimen sungai, seperti untuk percontoh uji mineral, tanah, felpar, granit, zeolit dan lain sebagainya.

\section{Saran}

Laboratorium pengujian terutama metode XRF perlu dilengkapi dengan berbagai jenis CRM. Oleh karena metode pengujian dengan XRF dalam pembuatan satu aplikasi pengujian sejenis diperlukan data base berbagai kurva kalibrasi, akan lebih baik bila tersedia lebih banyak variasi CRM.

\section{UCAPAN TERIMA KASIH}

Penulis mengucapkan terima kasih kepada Kartiwa Sumadi, M.Chem yang selalu memberikan dukungan, dan Ir. Tatang Wahyudi, M.Sc. atas bimbingan dan masukan sehingga tulisan ini dapat dihasilkan dengan baik, serta rekan-rekan di Laboratorium Fisika Mineral atas kerjasama dan dukungannya.

\section{DAFTAR PUSTAKA}

Bertin, E. P. (1984) Principles and practice of X-ray spectrometric analysis. 2nd Ed. New York: Plenum Press.

China National Analysis Center for Iron dan Steel (2010) "Certificate of certified reference materials NCS DC 73312a dan NCS DC 73313a stream sediment." Beijing: China National Analysis Center For Iron dan Steel.

Govindaraju, K. (1989) "Geostandards newsletter," Geostandards and Geoanalytical Research, 13(2), hal. 195-195. doi: 10.1111/j.1751908X.1989.tb00832.x.

KAN (2002) Pedoman evaluasi pelaporan ketidakpastian pengukuran (DP.01.23). Jakarta: Komite Akreditasi Nasional.

Kantasubrata, Y. (2014) Diklat teknik estimasi ketidakpastian pengukuran kimia: Dasar ketidakpastian pada pengujian. Jakarta: Badan Standardisasi Nasional.

Lemigas (2017) Sertifikat kalibrasi timbangan analitik No. sertifikat: SK-4518. Jakarta: Lemigas.

Rousseau, R. M. (2001) "Detection limit and estimate of uncertainty of analytical XRF results," The Rigaku Journal, 18(2), hal. 33-47.

Setiati, N. R. (2018) "Estimasi ketidakpastian pengukuran dan pengujian kuat tekan beton," Jurnal Jalan Jembatan, 23(3), hal. 1-15.

Sukirno, S., Murniasih, S., Rosidi, R. dan Samin, S. (2015) “Evaluasi ketidakpastian pengukuran multi-unsur dalam mineral zirkon dengan metode analisis aktivasi neutron," Eksplorium, 36(1), hal. $45 . \quad$ doi: 10.17146/eksplorium.2015.36.1.2770. 
Sukirno, S. dan Taftazani, A. (2010) "Penafsiran nilai ketidakpastian analisis $\mathrm{Fe}, \mathrm{Ca}, \mathrm{Zr}$, Ba, La, Ti dan Ce dalam cuplikan sedimen dengan metoda XRF," Ganendra Majalah IPTEK Nuklir, 13(1). doi: 10.17146/gnd.2010.13.1.43.

Sumadi, K., Gunawan, G. dan Rohayati, Y. (2004) "Pengkajian pengembangan pasir besi untuk acuan standar analisis kimia," Bahan Galian Industri, 8(23), hal. 23-30.

Sumadi, K. dan Rohayati, Y. (2003) "Ketidakpastian analisis bahan galian felspar dengan teknik XRF spektrometri," Buletin Bahan Galian Industri, 7(18), hal. 17-26. 
